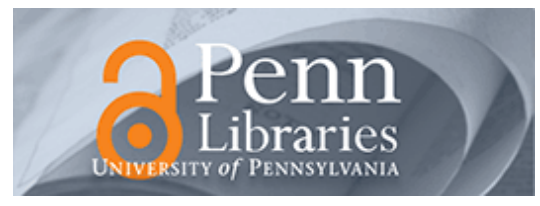

Studies in Visual Communication

Volume 9

Issue 2 Spring 1983

Article 4

1983

\title{
Review Essay: Vito Russo, The Celluloid Closet: Homosexuality in the Movies
}

Richard Dyer

\section{Recommended Citation}

Dyer, R. (1983). Review Essay: Vito Russo, The Celluloid Closet: Homosexuality in the Movies. 9 (2), 52-56. Retrieved from https://repository.upenn.edu/svc/vol9/iss2/4

This paper is posted at ScholarlyCommons. https://repository.upenn.edu/svc/vol9/iss2/4

For more information, please contact repository@pobox.upenn.edu. 
Review Essay: Vito Russo, The Celluloid Closet: Homosexuality in the Movies 


\section{Review Essay: Vito Russo, The Celluloid Closet: Homosexuality in the Movies}

\section{Richard Dyep}

Vito Russo's The Celluloid Closet is the first book to offer a history of how gays have been portrayed in the cinema. There have been series of articles in gay magazines presenting chronologies of gay characters in films, and two books - Parker Tyler's characteristically elusive, suggestive critical ruminations in Screening the Sexes (1972) and the British Film Institute publication Gays and Film (Dyer 1977), which raised some of the theoretical problems involved in thinking about homosexuality and film. The Celluloid Closet is the first survey/history book on the subject. It is clearly, fluently written, marvellously illustrated, and very informative, a more or less essential book for anyone concerned with the way that our century has constructed and inflected the notions of sexuality and homosexuality and the roles of the heterosexual and the homosexual.

Just because it is such an important book, it deserves more than the rather too easy praise it has generally received. What follows is in two sections: one, a relatively conventional "review," concerned with what the book is about and how it works as a book; the other, an attempt to draw out some of its implicit issues. In the rush to be comprehensive, Russo has never quite pulled out and fully explored many of the controlling ideas of the book. This is a pity - it makes the book look less intelligent and less political than it is. At the same time, many of these ideas seem to me to be caught at a transition point in current developments in theories of sexuality, and of gayness in particular, so that many unresolved problems remain.

The Celluloid Closet shares the problems of some other pioneering works dealing with the representation of social groups, such as those by Molly Haskell (1974) and Marjorie Rosen (1973) on women; Donald Bogle (1973), Thomas Cripps (1977), and Jim Pines (1975) on blacks; and Ralph and Natasha Friar on Native Americans (1972). It is not easy to write such a book, and one of the major difficulties is organization. Russo is trying to do three things at once, each important and each necessary. First, he is providing a survey of what have been the main ways in which gays have been represented in films, a catalog of types and images. Second, this basically synchronic enterprise is crossed with the diachronic aim of providing a history of gay filmic representation, relating the development of the images to changes in both the situation of gay people and the institutions of the cinema. Third, Russo offers a critical perspective on

Vito Russo. The Celluloid Closet: Homosexuality in the Movies. New York: Harper and Row, 1981. $\$ 7.95$ (paper) the films, at once aesthetic and political. Partly because of pressures of space and the need to produce something easy to read, he has not entirely satisfactorily worked out a way of combining these three different elements.

To put it simply, I often found it quite hard to work out where the book was going (which is not to deny that it is very easy and pleasant to go along with the book's effortless readability). Thus the first section of the book, "Who's a Sissy?," focuses on the homosexual man represented as effeminate. Russo has uncovered a mass of unfamiliar material and he presents it well. But then the chapter rather falls apart as he tries to examine both the persistence of the sissy in later periods and what else was going on in the earlier period, and somehow that brings us round by the end of the chapter to a survey of gays in horror films. In between we have a rather thinly informed excursion to German films of the twenties and thirties. None of this deals with the historical specificity of the films except in the vaguest way.

The same sorts of problems plague the other chapters. Each chapter covers a period: Chapter 2 deals with the Hays Code-dominated Hollywood production; Chapter 3 with the gradual emergence of "adult," "sexual" themes in the fifties and sixties; and the last chapter with the relationship between cinema and movements for sexual liberation. Admirably, Russo does not want to remain within the somewhat suspect straitjacket of periods; his method of extending outward from a given period to show how a character type produced in one historical moment has a life beyond that particular moment is potentially a very useful one. The problem is that his procedures are not always clear, and the book reads muddled.

Then there are questions of interpretation and evaluation. The book slips between saying what a film means, what its value is from a sexual political standpoint, and whether it says it well. In each case, Russo does not have space to make a full argument and does not always make a very clear one. When one knows something about the films in question, one finds his remarks sometimes (not often) factually inac curate, or questionable interpretations, or controversial judgments - and that then begins to make one wonder about the accounts of films with which one is not familiar. European cinema is given a bit too easy a ride; there is a lingering sense of the old critical equations of Hollywood is fun but trash and European cinema is Art. Russo does, moreover, seem to have a category of film "quality" separable from ideological meaning, and while aesthetic questions cannot be collapsed into ideological ones, equally notions of "quality" are highly problematic and a well-made film does not make up for reactionary politics. Finally, in terms of coverage the book is really about Hollywood and mostly about male gay representation. There are 
surprising omissions, and the filmography in particular is oddly selective, without an explanation of the principles of selection. None of this alters the fact that Russo has produced a book of major importance, mapping out the territory of gay representation and uncovering much forgotten material and many hitherto unsuspected titles. The question is what to do with this information, what sense to make of the territory.

One of the difficulties in thinking about anything to do with homosexuality, and sexuality in general, is determining whether the object of one's thought is what society has done with homosexuality at a given point in time or how homosexuality has been socially constructed at a given point. The distinction is crucial, but hard in practice to keep in focus. In the first case, we are talking about something we assume exists before society gets hold of it, whereas in the latter we assume that homosexuality is itself socially produced. It is a question of degree. While there are essentialist positions that see (homo-) sexuality as a given human quality that is the same the world over and throughout human history, most would agree that how any society thinks and feels about (homo-)sexuality, and so lives (homo-)sexuality, is socially constructed. Equally, while many current theories of sexuality emphasizing it as a social construction give the appearance of meaning that it is a category of discourse entirely invented and produced over the past two or three centuries, the theoreticians must posit some kind of raw material, of human physical activity, out of which ideas of sexuality, homosexuality, gayness, friendship, and so on, are fashioned. We need to develop a way of thinking which recognizes the human body and its potentials as theoretically separable and relatively autonomous from the social/cultural/human and yet also encompasses the understanding that we can have very little knowledge or experience of that body except through socially, culturally, humanly specific ways of conceptualizing and feeling it. At present the difficulties of thinking through and holding together in one's mind this relationship between the biologically given (always remembering that "biology" is itself a particular way of making sense of the body) and the ineluctable practices of social construction tend to be too great, and it is hard not to put too great an emphasis on one or another dimension, falling back into essentialist or pure social constructionist conceptualizations. Where one puts the emphasis is crucial, however, and politically so. (For further consideration of these issues see Barrett 1980:Chaps. 2, 3; and Plummer 1981, especially the articles by Mclntosh and Weeks.)

Both conceptualizations may issue in forms of radical politics, and I would like to characterize the difference in the gay context as between "gay liberationist" and some other kind of gay politics that has not yet acquired a name but that I would want to claim is a social materialist politics (see discussion in Watney 1980:64-76). "Gay liberationist" politics was based on a conviction that gayness has certain inherent qualities that straight/bourgeois/patriarchal society had buried away; they needed releasing; and the very act of releasing them was an act of revolution against the society that had repressed them. The other kind of politics starts from the assumption that homosexuality is a social category forming part of a general system of regulating sexuality, whose broad function (and the trouble with this approach is that the function is so broad) is to keep people in their (social) place by assigning them a sexual place - that is, by assigning them a social place (heterosexual, homosexual, bisexual, frigid woman, rapist, masturbator) through the regulation of what appears to be the most intimate and urgent arena of human experience, sexuality (see Foucault 1976). A politics that starts at this point is both more negative and more positive than a gay liberationist one. It is more negative partly because it does not have one vivid, inspiring focus ("gay is good") and because it deals with and on behalf of a category which it itself defines as socially constructed (and thus arbitrary and limiting, and probably to be moved beyond). But it is more positive because it insists on a recognition of social construction, on the fact that most everything in human affairs has been constructed and therefore that most anything can be: it returns to politics the utopian project of what we want to construct rather than what we want to release. (It also, but this is a further argument, frees us from the tyranny of sex, whereas gay liberationism was in danger of reinforcing that tyranny.)

It will be clear where my own convictions lie, but this does not mean that the gay liberation movement was not, and is not, enormously progressive; nor does it mean that gay people have to abandon organizing around a gay identity. Quite apart from the continued need to defend our gay practices from oppression, we can work only within the social categories that exist; we cannot just "become" something other than "gay." But we can be working to establish a society in which the possibilities of the body are radically, differently understood and cherished.

Vito Russo's book seems to be caught between the two perspectives outlined above. This can be seen in his treatment of three key areas - the relationship between sexuality and gender, the nature of male-male friendship, and the question of the gay sensibility.

Russo rightly stresses the role of the sissy image in relation to gay male characters. He points out that the tomboy image is far less a focus of derision and implied homosexuality, since it expresses an aspiration toward things manly and is therefore understandable, whereas the sissy is reaching for womanly attributes. Implicit in this analysis is both the idea that womanliness is regarded as weak or despicable (and there- 
fore demeaning for a "real" man) and the idea that the male role is particularly narrow and rigidly defined, so that its preservation (and male power along with it) is peculiarly precarious, because it is so unattractive, allowing even less leeway than the female role. (The point here is not that the female role is not also narrow, but rather that it is understood to be properly narrow, and therefore something that a girl might try to get away from even if she should learn restraint eventually - the structure of numerous films centered on spunky heroines; but the narrowness of the male role is not acknowledged, and hence anything which draws attention to it-like sissinessmust at the samie time be ridiculed out of court.) Russo has, then, a complex, flexible, and original model of the interplay between gender and sexuality, between how to behave like a man and the imputed sexuality of people who behave like men, and he applies this model sensitively and productively to the films.

The model of a sexuality-gender nexus gives homosexuality a kind of "in-between" status, homosexuality as a refusal of, and therefore a threat to, traditional gender roles. But is this the case? What clearly is the case is that, at the level of public discourses on sexuality, homosexuality has been understood as inbetweenism, and this is as true of much progressive gay thought (e.g., Edward Carpenter, Magnus Hirschfeld, Charlotte Wolff) as of antigay thought. At this level Russo is describing an indisputable aspect of the social construction of homosexuality. Many of the illustrations in his book clearly show that a play on the signifiers of masculinity and femininity is what allows a figure to be read as gay. The assumption of a gender in-betweenism that is then taken to indicate a specific sexuality was equally made quite explicit in a sequence of photographs produced by the Scientific Humanitarian Committee in 1903 in Germany, illustrating the heterosexual male, the heterosexual female. and the non-male, non-female homosexual in-between (see Lauritsen and Thorstad 1974 and Steakley 1975.)

What is not clear-in current sexual theory no less than in Russo's book -is whether this in-betweenism, even if no longer biologically conceptualized, is true in the sense of homosexuality's being, inherently almost, a refusal of gender roles. While at the macro level of mass-circulation discourses the construction of homosexuality is offered on the model of gender inbetweenism, the actual histories of lesbians and gay men seem as often to involve constructing their sexuality out of, and within, the models of traditional masculine/feminine psychology that are offered them. Why a model of homosexual biography - gay men and lesbians as the most rather than the least masculine and feminine practitioners of sexuality, respectively - has not got into the mass media and the dominant discourse on homosexuality is not a question I know the answer to. But pointing to it does mean that we have to be a bit more careful about our assessment of the sissy.

Russo seems to want to have it both ways with the sissy. He wants to point out its ideological role of shoring up heterosexual gender roles; but he also wants to say it carries within it the seeds of revolution because it does not fit those gender roles. In charting the former, the operations of gender ideology, he is on firm ground, but on the latter he is near to going along with the model of in-betweenism.

If they see themselves as profeminist, gay men can choose to use the sissy as some sort of model of how not to be "masculine"; this is our historical legacy, as it were, which may help in finding styles of fighting gender roles. But gender roles are not so invariably and rigidly decisive in the construction of homosexuality in the way in-betweenism suggests. Gay struggle against gender roles relates only to homosexuality itself insofar as, at the level of public representation, the two have been brought together; and this misses many other ways in which homosexuality is constructed (and oppressed) through the categories of male and female sexuality

A perennial theme in gay (film) criticism has been the question of male-male friendships on screen, the buddy image. Are such images implicitly gay or a denial of gayness? Should we see Butch Cassidy and the Sundance Kid as "really" a gay relationship or as a relationship in which gayness has been deliberately suppressed? Or is it not gay at all in any sense?

One set of problems in relation to this has to do with procedures of textual criticism. Gay criticism has to deal with the fact that it is not always easy to know with any certainty whether a character is to be read as gay, because gayness is not something that is visible; it does not "show" as gender or race does. (This is in any case more complex than it appears-gender and race are less hard-and-fast as categories than we are generally led to suppose. Most representation of people of different genders or races involves a mass of signifiers in excess of the very limited and largely ambiguous signifiers of difference given by nature, but with gays, as with class, there are no given signifiers of difference whatsoever. See Perkins 1979.) Russo is very careful in his treatment of this problem. He does not get involved in the kind of reading-in of gayness that many critics go in for. This is partly because he argues from the film texts, clearly showing what the evidence is for reading a given character or sequence as gay/homosexual. Eyebrows may be raised at his inclusion of Laurel and Hardy as a gay couple in several of their films, but the argument is supported by evidence from the films themselves. In addition, Russo is arguing from a definition of gayness as a recognizable cultural 
form - the signs of gayness are those produced to define gayness, whether by dominant or gay subcultural practices, and it is from these that he is producing his readings. In this way he is very different from those critics, largely psychoanalytic by persuasion and heterosexual by implicit self-definition, who do see homosexuality represented where there are no such signs of it. What this implies is that gayness as subcultural sexual practice and homosexuality as a description of a given human relation are not coterminous - not all people who have same-sex sexual contact are, or identify themselves as, gay. (Let me leave for now the ambiguity over whether one can be gay without identifying oneself as gay, a problem which is yet another road back to the essentialist/social constructionist divide.)

These problems of textual interpretation themselves derive from a second set of problems that are focused on the question of male-male friendships. Critics, gay and otherwise, often make the assumption that intense male-male friendship, in life as in movies, is always and necessarily sexual. This is a thorny question, but it would seem that it is at least dangerous to assume a priori that same-sex friendship is by definition sexual. This is the nub of the problem that Michel Foucault's influential work raises in relation to psychoanalysis, which has been the main route through which the idea of the sexuality of human relations hitherto not considered sexual has come to us. Freud's recognition of the crucial role of intense physical relations in childhood (in the child itself, between the child and others) seems like a real gain, a real departure from attempts to deny the body; but securing it, as Freudianism has, so inexorably to notions of sexuality seems part of a tyranny whereby sexuality is the explain-all of life.

Lillian Faderman's Surpassing the Love of Men (1981) argues very clearly the difficulty of necessarily assuming that we must call intense female-female relationships in earlier periods, or even our own, lesbian (see also Clark 1982 for a recent discussion of the use of the term lesbian in the women's movement). It would be wrong to make a simple transferral of this female experience to the male one, partly because awareness of sexuality seems more constructed into male experience generally in the periods Faderman covers. Equally, however, we need to resist the temptation, to put it bluntly, of seeing everything in terms of sex. That the intensity of friendship has a bodily dimension is one thing that we need to recognize, but the body cannot be reduced to "sexuality," which is a very specific concept of genital determination.

Bringing these textual and conceptual sets of problems together, we might argue in analyzing a buddy film that it operates with a concept of male-male friendship as sexual through its deployment of signifiers that indicate this. But it would be a different ar- gument from saying that the film shows, or thinks it shows, an intense but nonsexual friendship between two men but that "really" the relationship is sexual because "really" all such relationships are. To call on this "really" here is to fall back into an essentialist position, which not only takes homosexuality as a given but also prioritizes the sexual in the understanding of human relationships. The problem with doing this is not just an intellectual one: by reinforcing the prioritization of sexuality we are in danger of acceding to a regime whereby we are controlled through our sexuality

Russo is clearly caught up in these difficult ideas, and here flatly contradicts himself. He argues that buddiness is always constructed around a denial of homosexuality, but whereas on page 70 he writes that "gays are the manifestation of what stands between men's complete love of other men and their acceptance of women as friends" so that "men have never been granted the full emotional potential that they might have had on the screen," on page 148 he writes, "The appeal of the buddy relationship for heterosexual men has always been that of an escape from the role playing of men and women-a safe, neutral emotional zone with no chance for confusion." In the first case, buddiness is all but sexual, and intense and angst-ridden because of it; in the second it is thankfully not sexual, and a relief because of it. Male-male friendship, in reality or as represented, may be either, and we would do well not to start from the assumption that such a friendship is in some sense or other gay. To say that Butch and Sundance are gay was, at a certain time, outrageous and liberating; to go on saying it may be to reproduce the regime of sexuality.

A third reworking in The Celluloid Closet of what I am calling a gay liberationist versus a social materialist theory/politics comes out in the treatment of the idea of the "gay sensibility." Here Russo is concerned to show that anything which might constitute a sensibility is rooted in the actual material situation of gay people-ghetto cultures, the experience of passing, the fact of being defined as deviant. So far so good. There is such a phenomenon as a gay sensibility, that is, a characteristic way of feeling about things which has been produced out of the material circumstances of gay people and which gays learn as they come out into any developed gay subculture. The limitations of saying this need to be kept in mind: the situation of gay people did not give off the sensibility; it was the situation within which the sensibility was produced and about which it made a sense. And it has to be learned; one would not automatically have it without coming into contact with it somehow. Russo slips from the first, materialist, position to a second, essentialist, position, which sees gays as inevitably having a sensibility of "difference." 
Russo's desire to hang on to a distinctive gay difference underpins many of his judgments. As a protest against blandness, I feel with him-the gay sensibility is much more fun, much more alive than the straight one. As a basis of action on the basis of a sense of shared feeling, this is good politics. But we should recognize that we have produced this sensibility in history and that we choose to promote it for what is good about it (recognizing, too, that many things about it are sexist, snobbish, and self-oppressive). It seems like freedom to assert the right to express a pregiven gay sensibility, but it is another and perhaps greater kind of freedom to assert the choice of constructing a kind of sensibility and determining the form it takes.

The importance of Vito Russo's book is that it both allows one to see clearly many of these difficult issues and gives one much-needed information and evidence with which to think them through. The problems of the book are not problems unique to Russo; on the contrary, they are the central problems of sexual political debate. In trying to outline some of them, I wish to emphasize the problems I share with him rather than suggest an intellectual distance from him.

\section{References}

- Barrett, Michèle

1980 Women's Oppression To-day: Problems in Marxist Feminist Analysis. London: Verso.

- Bogle, Donald

1973 Toms, Coons, Mulattoes, Mammies and Bucks: An Interpretive History of Blacks in American Films. New York: Viking.

- Clark, Wendy

1982 The Dyke, The Feminist and the Devil. Feminist Review $11: 30-39$

- Cripps, Thomas

1977 Slow Fade to Black: The Negro in American Films, 1900-1942. London, Oxford, New York: Oxford University Press.

- Dyer, Richard, ed.

1977 Gays and Film. London: British Film Institute.

- Faderman, Lillian

1981 Surpassing the Love of Men. New York: William Morrow.

- Foucault, Michel

1976 La Volonté de savoir. Paris: Gallimard.

- Friar, Ralph E., and Natasha A. Friar

1972 The Only Good Indian ... The Hollywood Gospel. New York: Drama Book Specialists.

- Haskell, Molly

1974 From Reverence to Rape. New York: Holt, Rinchart and Winston.

- Lauritsen, John, and David Thorstad

1974 The Early Homosexual Rights Movement, 1864-1935. New York: Times Change Press.

- Perkins, T. E

1979 Rethinking Stereotypes. In Ideology and Cultural Produc-

- Pines, Jim tion. M. Barrett, P. Corrigan, et al., eds. London: Croom Helm.

1975 Blacks in Films. London: Studio Vista

- Plummer, Kenneth, ed.

1981 The Making of the Modern Homosexual. London: Hutchinson.

- Rosen, Marjorie

1973 Popcorn Venus. New York: Coward, McCann and Geoghegan.

- Steakley, James D.

1975 The Homosexual Emancipation Movement in Germany. New York: Arno Press.

- Tyler, Parker

1972 Screening the Sexes. New York: Holt, Rinehart and Winston.

- Watney, Simon

1980 The Ideology of GLF. Homosexuality: Power and Politics. Gay Left Collective, eds. London: Allison and Busby. 